Studia Anglica Posnaniensia 47, 2-3, 2012

doi: 10.2478/v10121-012-0002-z

\title{
THE MIDDLE ENGLISH SUFFIX -ISH: REASONS FOR DECLINE IN PRODUCTIVITY
}

\author{
EWA CISZEK
}

Adam Mickiewicz University, Poznań

\begin{abstract}
The aim of the present paper is to investigate the reasons for the significant decline in both the frequency and productivity of the suffix -ish in Middle English. The major factors responsible seem to be the growing popularity of the of + Noun phrases as well as the competition among -ish and other suffixes.

The analysis will be preceded with the introduction of some essential facts concerning the semantic development and productivity of the OE suffix -isc in Middle English.
\end{abstract}

\section{Introduction}

In my research, I have mainly relied on electronic databases such as the Dictionary of Old English (A-F) and the Toronto Corpus of Old English Texts for Old English as well as the Middle English Dictionary online for Middle English. The study is supplemented with An Anglo-Saxon Dictionary by Bosworth and Toller (1898-1921), the Middle English part of the Helsinki Corpus and a number of complete Middle English texts. Taking into account such an extensive lexical material, I consider any $M E D$ derivative unattested in any OE database as a new coinage.

The analysis of the productivity of the suffix -ish in the period under discussion relies on the type value, as suggested by Dalton-Puffer and Cowie (2000). I will also occasionally quote the number of ME hybrids, which are an important indicator of productivity of the suffix they include (see Ciszek 2008a). 


\title{
2. The semantics of -isc in Old English
}

\subsection{Previous studies}

The OE suffix -ish has been subject to only narrow interest as demonstrated in merely a few dictionary entries and short descriptions among other affixes found in some Old English grammars or histories of English.

As regards dictionaries, Bosworth and Toller (1898-1921) and the OED online list it as a separate entry.

Bosworth and Toller (1898-1921) describe the suffix as follows:

\begin{abstract}
-isc, modern -ish, a suffix of adjectives, connoting the quality of the object denoted by the stem, e.g. ceoel-isc 'churl-ish', cild-isc 'child-ish'; also connotes origin from a place or stock, e.g. Engl-isc, Grēc-isc, Iudē-isc. The suffix may be seen in the cognate dialects in the following words, Goth. piud-isk-o 'after the manner of the Gentiles'; Iudaiw-isk-s; O. Sax. menn-isk human: O. Frs. mann-isk: Icel. bern-sk-r 'childish'; En-sk-r 'English': Engel-sk 'English': O. H. Ger. diut-isc: Ger. deut-sch; v. militisc.
\end{abstract}

The OED online gives a slightly more exhaustive description of the Old English -ish and defines it as

\begin{abstract}
a suffix forming adjs., of Com. Teut. origin; ... In words of old formation, the prec. vowel had umlaut (which was often present in the $\mathrm{n}$. whence the adj. in -isc was formed); ...

1. In OE. and the cognate langs., chiefly forming gentile adjs. from national names: e.g. British (OE. Brittisc), English (OE. Englisc, †Sc. Inglis), Scottish, Scotch (OE. Scyttisc, Sc. †Scottis, Scots), Irish (OE. Irisc), Welsh (OE. Wielisc, $\dagger$ Sc. Walys, Wallis); Danish (OE. Denisc, †Sc. Dense, Dence); Frankish, French (OE. Frencisc); ...

2. Added to other ns., with the sense 'Of or belonging to a person or thing, of the nature or character of'. These were not numerous in OE., whence only a few have come down to later times. Examples are folcisc popular, $h \overline{\mathfrak{x}}$ ðenisc heathenish, péodisc national, inlendisc inlandish, utlendisc outlandish (which come close to the gentile group in 1); also mennisc human, cildisc childish, cierlisc churlish.
\end{abstract}

The Old English suffix -isc has also been briefly considered among others by Wright (1914), Jespersen (1942), Quirk and Wrenn (1955 [2001]), Marchand (1969) and Kastovsky (1992). They generally restrict their discussion of -isc to mentioning the fact that it was a denominal suffix especially used to derive ethnic adjectives, which the authors illustrate with some examples.

\section{2. -isc in Old English}

There are 168 denominal -isc derivatives attested in my Old English database. The suffix in them generally added the sense 'a quality'. 
More specifically, in 119 words -isc was attached to place-names or to nouns denoting groups of people inhabiting a given place and it assumed the meaning 'of a certain nationality/origin'. 62 of such words functioned exclusively as adjectives. Here one can quote examples such as Bulgarisc 'Bulgarian', Lindisfarneisc 'of Lindisfarne', Numentisc 'of Numantia', Sicilisc 'Sicilian', Sidoneisc 'of Sidon', Speonisc 'Spanish' and Wincestrisc 'of Winchester'.

36 of the derivatives could function as both adjectives and nouns (usually in the plural). In 23 of them the suffix -isc apart from adding the sense 'of a certain nationality/origin' in some context might also assume the sense 'a group of people of a certain nationality/origin'. Here belong coinages such as, for instance, Alexandrianisc 'an Alexandrian', Babilonisc 'the Babylonians', Centisc 'the Kentish' and Macedonisc 'Macedonians'. In the other 4 derivatives the suffix could refer to both 'a certain nationality/origin' and 'the language of a certain nationality' as in, e.g., Brittisc 'British, referring to Brittonic speakers', Bryt-wylisc 'British, referring to Brittonic speakers', Denisc 'Danish (i.e., Norse, Scandinavian)', or Scottisc 'Scottish'. In the remaining 9 formations the suffix -isc could add all three senses mentioned above. These are: Denisc 'Norse', Ebrēisc (Hebrēisc) 'Hebrew', Egiptisc 'Egyptian', Englisc 'English', Frencisc 'French', Grecisc 'Greek', Indisc 'Indian', Rōmānisc 'Roman' and Syrisc 'Syrian'. Interestingly, all these words, except Syrisc, survived into Middle English. I assume this was due to the frequent use of the formations with various meanings of the suffix.

Finally, 21 -isc derivatives from place-names are attested exclusively with a nominal function. In 18 of them the suffix -isc assumes the sense 'a group of people of a certain nationality/origin', e.g., Hamtunisc 'inhabitants of Northampton', Hierosolimisc 'people of Jerusalem', Moabisc 'people of Moab' and Perscisc 'Persian'. In the remaining 3 formations, i.e., Ethiopisc 'Ethiopic', Norðhymbrisc 'Northumbrian' and Pihtisc 'lg. of the Picts' the suffix adds the sense 'the language of a certain nationality'.

The suffix -isc could also be attached to personal names. In the database, I have attested 15 such coinages, e.g., Ambrōsianisc '(composed) by St. Ambrose', Davidisc 'of or by David (referring to the psalms)', Ismaelitisc 'of Ishmael' and Magdalenisc 'of Magdalene'.

Additionally, there are 34 derivatives from common nouns, e.g., cildisc 'of a child; of tender age', cristallisc 'of crystal', gimmisc 'jewelled' and heofenisc 'heavenly'.

Finally, it is worth pointing out that six of the OE -isc formations attested in my database are not included in the Dictionary of Old English (A-F). These are: Adolamitisc 'of Adullam', Ammonisc 'of Ammon', Antiochisc 'Antiochian', Armenisc 'of Armenia', Beadonesc 'of (Mount) Badon' and deuelisc 'devilish'. 
3. The semantics of -ish in Middle English

\subsection{Previous studies}

The ME suffix -ish has been briefly treated by Jespersen (1942), Fisiak (1965, 1968 [2004]), Marchand (1969), OED online, Dalton-Puffer (1996) and the MED online.

Jespersen (1942: 323), Fisiak (1965: 65, 69, 1968 [2004]: 110), Marchand (1969: 243-244) and the OED online note that in Middle English the suffix -ish started to derive adjectives also from other adjectives and illustrate it with a few examples. Jespersen and Marchand follow the $O E D$ and mention that the process started from colour terms to which the suffix added the meaning 'somewhat, rather, approaching the quality of'.

Dalton-Puffer (1996: 172), in her database, i.e., the first three subperiods of the Middle English part of the Helsinki Corpus (1150-1420), found -ish derivatives only from nouns. Semantically, she describes them as having the meaning 'of the nature of -, having the character of -'.

The most extensive definition of the suffix has been provided in the MED:

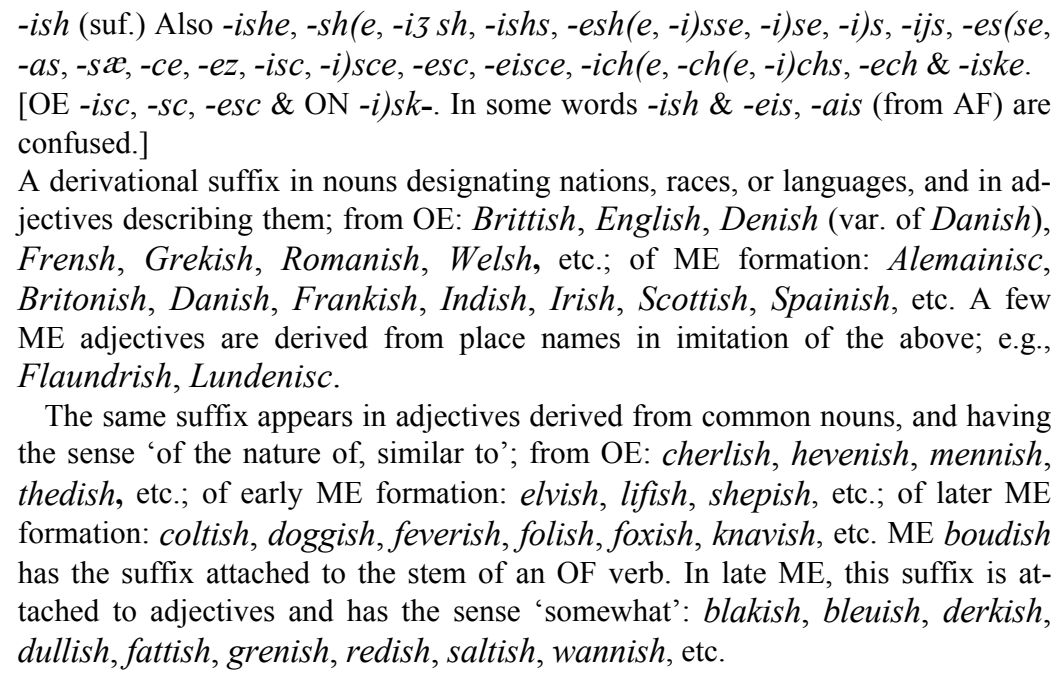

The same suffix appears in adjectives derived from common nouns, and having the sense 'of the nature of, similar to'; from OE: cherlish, hevenish, mennish, thedish, etc.; of early ME formation: elvish, lifish, shepish, etc.; of later ME formation: coltish, doggish, feverish, folish, foxish, knavish, etc. ME boudish has the suffix attached to the stem of an OF verb. In late ME, this suffix is attached to adjectives and has the sense 'somewhat': blakish, bleuish, derkish, dullish, fattish, grenish, redish, saltish, wannish, etc.

\section{2. -ish in ME formations inherited from Old English}

There are $47 \mathrm{OE}$-isc words recorded in the Middle English material available: 40 continued to be used in Early and sometimes also Late Middle English and the other seven reappeared only in Late Middle English. The MED lists 10 of these derivatives (about 20\%) as new coinages, which does not seem to be correct in view of the available evidence. I have found all the derivatives in the Toronto 
Corpus of Old English Texts. Here they are: Britonish 'Celtic, British' (1275), Caldeowish 'Chaldean' (1200), elvish 'belonging or pertaining to the elves; possessing supernatural skill or powers' (1275), Flèmish 'from Flanders, of the Flemings, Flemish' (1325) and 'Flemish people, the Flemish language' (1325), Irish 'of Irish nationality; found or produced in Ireland; characteristic of Ireland' (1275), Israèlìtish 'belonging to ancient Israel' (1175) and outlondish 'foreign' (1300) for Early Middle English as well as dèvelish 'devilish, fiendish, wicked' (1439), Devenish 'of Devonshire' (1451) and Indish 'Indian' (1398) for the latter period of Middle English. The suffix mostly preserved its OE senses and usually referred to 'a certain nationality/origin' and the base was a place-name.

The remaining 37 derivatives also continued to be used with more or less the original senses of -ish. Of these, 23 are formations derived from place-names.

\section{3. - ish in new EME coinages (1150-1350)}

The MED online treats 27 -ish derivatives as originating in Early Middle English. The information provided for 10 of them, which means some $40 \%$ (!), is apparently misleading. These formations can actually be traced back to Old English. ${ }^{1}$ For the list of words see above.

As regards the 17 truly new EME coinages recorded in the corpus, they are all derived from nouns. Seven of them follow the prevailing OE pattern and are derived from a place name. These are: Alemainisc (1275), Lombardish (1275), Marchisce (cf. OE Mircisc) (1275), Norenish (1275), Peitish (1275), Spainish (cf. OE Speonisc) (1275) and Corn-walish (1325).

Moreover, one adjective, i.e., Jüdeuish (1200) is derived from a noun denoting 'a representative of an ethnic group'.

The remaining nine formations are coined on common nouns. Here belong: sindōnish (1150), līfish (1200), shēpishe (1200), nētish (1225), rotherish (1225), swinisc (1225), carlish (1250), londish (1300) and mopish (1300).

Among the derivatives mentioned above one can recognise six hybrids, which is quite a high percentage. Marchisce, Peitish, Spainish and Jüdeuish ${ }^{2}$ are based on Old French stems, carlish on Old Norse and sindonish on Latin one.

\section{4. -ish in new LME coinages (1350-1500)}

This group is considerably more numerous and includes 118 coinages. Of these there are 79 derivatives from nouns, 35 from adjectives, two from verbs, one probably from a past participle and one, i.e., loumish of unknown origin.

\footnotetext{
1 The word ambrōsiānisc, which comes from the Winteney version of the Benedictine rule (1225), was completely excluded from my ME database. The text is a literatim copy of the OE manuscript (see also Ciszek 2008 a and b).

2 Jüdeuish could have also been derived from L Jüdaeus.
} 
As regards denominal formations, the suffix -ish in them assumes the sense 'a quality characteristic of'. Structurally, there are only 6 examples which would follow the OE pattern, i.e., the base is a noun denoting either a placename or a representative of a given nation. The prevailing majority, i.e., 73 of the denominal -ish coinages is derived from common nouns. It is remarkable that a number of these refer to either a person (12) or an animal (17).

About $30 \%$ of all LME -ish formations are derived from adjectives. Here, the suffix assumes the sense 'somewhat'. The coinages can be divided into those formed from colour terms (12) and those from other adjectives (23). It is interesting to notice that these two patterns seem to be initiated by Chaucer.

The number of hybrids recorded in the LME material available is significantly high: 29 are coined on Old French bases, five on Old Norse, two each on Anglo-French and Middle Dutch and one each on Medieval Latin and Old Icelandic.

\section{Productivity}

The only author dealing with the productivity of -ish in detail is Dalton-Puffer (1996). In the Helsinki Corpus she finds 16 types of -ish in Early Middle English and 2 in ME3 (1350-1420). Dalton-Puffer does not indicate exactly how many of these were new coinages but mentions that "[o]nly a fairly small share of ISH-adjectives are actually analyzable on a Middle English basis. Most of the adjectives ... have been inherited from Old English" (1996: 172).

My study has revealed that new ME coinages had a higher frequency of occurrence. 17 have been recorded by the $M E D$ for Early Middle English and 118 for Late Middle English. In the period 1350-1420, for which Dalton-Puffer quotes 2 -ish types, I have found 48 new coinages.

Moreover, a noteworthy number of hybrids, i.e., 6 in Early and 40 in Late Middle English contribute to the productivity of the suffix.

5. Analysis: Reasons for the decline in productivity of ME -ish

A peculiar observation is that the productivity of -ish is considerably low in Early as compared to Late Middle English. Also, if we look at the frequency of 168 OE derivatives and the fact that only 47 (less than 30\%) of them have been inherited into Middle English, we can claim that there was a significant decline in the popularity of the suffix -ish in Early Middle English. The general picture of the situation, resulting from what I have described more in detail above, is that -ish was gradually losing its primary OE sense, i.e., 'of origin'. The productivity of -ish in Late Middle English was boosted only by the fact that the suffix was more and more frequently added to common nouns and also a new para- 
digm was developed, i.e., coinages on colour terms and other adjectives with -ish assuming the sense 'somewhat'.

The potential reasons for the drop in both the frequency and productivity of ish with the sense 'of origin' in Middle English are the following: (1) some competing suffixes (also French) started to be successfully applied instead of $-i s h$ and (2) the -ish adjectives were replaced with of + Noun phrases. ${ }^{3}$

\subsection{Suffixes}

\subsection{1. -ian}

Dalton-Puffer (1996: 173) speculates that "ISH ceased to be a popular suffix for forming ethnic adjectives in English, possibly through the competition from the Romance IAN which served the same purpose". This suggestion seems quite convincing. However, Dalton-Puffer does not consider the suffix -ian separately and does not provide any statistics for it either.

In my search in the MED I have found 41 -ian adjectives or adjectives functioning as nouns in which the suffix adds the sense 'of origin'. ${ }^{4} 27$ of them are derived from place-names and 14 from nouns denoting people. These 41 -ian as against only 14 new -ish coinages make Dalton-Puffer's assumption plausible. If we divide Middle English into two subperiods we can see that in Early Middle English -ish is attested in 8 new coinages whereas -ian is introduced in four derivatives. Thus, -ish is still the dominating suffix. In Late Middle English the situation is reversed; there are only 6 new coinages in -ish and 37 in -ian.

As regards the competition between -ian and -ish, eight new ME -ian derivatives referring to the nationality/origin/belonging completely ousted the $\mathrm{OE}$-ish words. These are: Sirīen ${ }^{5}$ (1150), Arabien (1375), Ethiopien (1325), Macedoniens (nom. pl.) (1400), Persien (1400), Philistienes (nom. pl.) (1375), Tìrien (1400) and Effêsians (nom. pl.) (1430). Moreover, the word Samarian appeared only once in 1175, whereas Samaritanisc was attested in Old English and in 1150. OE Egiptisc can be found in the MED only once in Lambeth Homilies (1225) In 1300 Egipcien is coined and starts to be frequently used by various authors. Similarly, OE Troisc ${ }^{6}$ after appearing twice in Lazamon's Brut (1275) is abandoned for the sake of Troian (from 1387 as a noun; from 1425 as an ad-

3 Surely, also the number of new -ish formations on common nouns would have been higher if it had not been for competing suffixes such as -ly (-lich(e)), -i or -ine which displayed similar semantic profiles. (For a broader discussion of -ly (-lich(e)) see Ciszek (2002); for $-\bar{\imath}$ and -ine see also below).

4 There are some more -ian derivatives from common nouns. The same of course refers to -ish adjectives.

5 From OF syrien, surien and OE Syrian (gen. of Syria).

$6 \quad$ A parallel form Troianisc was also attested. 
jective). The OE word Indisc is revived only in 1398 by Trevisa. In a slightly earlier text, i.e., Gower's Confessio Amantis (1393), we find the word Indien, which later appears three more times in Kyng Alisaunder (1400) and once in Mandeville's Travels (1425); however, this is with a nominal function denoting an inhabitant of India or Indians collectively. Finally, adjectives derived from Latin personal names display a very interesting behaviour. In Old English the two attested derivatives, i.e., Arianisc and Pelagianisc, from Arius and Pelagius respectively, take both suffixes -ian and -isc. In Middle English they drop -isc.

\subsection{2. -ìte $(s) /$-ìtāne $(s)$}

A different suffix which turned out to be competitive towards -ish was -ite(s) and its related form -ittane(s). The MED treats the suffix -itt(e) as a separate entry and defines it as "[a] derivational suffix found in a few toponymics and racial names, chiefly from Latin". The analysis shows that -ìte(s) and -ìtāne(s) add the sense 'a person or a group of people (either inhabiting some place or followers or descendants of somebody)' and are attached to place-names or personal names respectively. In the MED I have found 22 formations including these suffixes. Seven of these derivatives are parallel to either OE or ME -ish formations. Five of them, i.e., Mōabìt(e) (1325), Jerosolomìtāne (1382) (Jerosolomìte (1500)), Ismaelītes (1387), Jacōbīte (1387) and Latīnitē $\bar{e}^{7}$ (1450) were used instead of the OE -ish derivatives which did not survive till Middle English. The OE adjective Samaritanisc 'of Samaria, Samaritan' appears only once in the MED in 1150 (see also 6.1.1. above). In the Wycliffite Bible (MS Douce 369,1384 ) the form is replaced by the adjective Samaritann(e) with the same meaning. In the same manuscript of the Bible the word Samaritann(e) is also used as a noun with the meaning 'an inhabitant of Samaria, a Samaritan'. Both forms are found in later texts. However, the nominal function seems more popular and in 1425 it is attested with the meaning 'Samaria'. The scribe of the MS Bodleian 959 (1382) of the Wycliffite Bible uses a related form Samarìtes denoting 'inhabitants of Samaria, Samaritans'. The word appears also in two later texts. The OE words Israēlish and Israèlitish are attested with the meaning 'belonging to ancient Israel; Hebrew, Jewish' only in four EME manuscripts. The noun Israèlìte(s) '(one of) the people of ancient Israel; also, member(s) of the spiritual Israel' can be found in the Wycliffite Bible (MS Douce 369, 1384).

\footnotetext{
7 Latīnitè 'Latin', a hapax legomenon, did not pose any competition to the word Latīn which replaced OE Lædenisc.

8 In the Toronto Corpus there is one occurrence of the noun Samaritān(e), which functions as the plural.
} 


\subsection{3. $-\bar{\imath} k$}

The other suffix competing with -ish was $-\hat{\imath} k$. The MED describes it as a "[d]erivational suffix in nouns and adjectives meaning 'in the nature of, pertaining to"". This definition does not include any examples of coinages based on place-names however. I have found seven such formations in the MED. Of these, four, i.e., Arabīk 'Arabic' (1325), Sirik 'Syriac, Aramaic' (1425), Galatike 'Galatian' (1440) and Memphetik 'of Memphis' (1450) appear instead of the corresponding OE -isc derivatives not recorded in the ME database. ${ }^{9}$ The fifth coinage, i.e., Ebraīk 'Hebrew, Jewish' (1390) replaced Ebreish 'of or pertaining to the Jews of Biblical times or their language, Hebrew; (b) as a noun: the Hebrews; the Hebrew language' inherited from Old English and documented between 1225 and 1325. For the other two derivatives, i.e., Marmorik(e) 'of the Roman territory of Marmarica in North Africa' (1425) and Italike 'Italian' (1440) there are no Old or Middle English -ish counterparts recorded in the database.

\subsection{4. $-\bar{a} n$}

$-\bar{a} n$ is another suffix which overlaps semantically with -ish. The MED characterises $-\bar{a} n$ as appearing "[i]n several nouns taken from Latin, denoting persons, as Affrican, publican". In the MED, I have found ten such coinages. Of these only Grēcan 'a Greek' (1500) shared the derivational base with the -ish formation going back to Old English and with the sense 'an inhabitant of Greece, a Greek' recorded till 1275. The words Grēcan and Thēbān are recorded also with an adjectival function, not mentioned by the $M E D$ in the definition of the suffix above. Thus, Greecan could also mean 'Grecian' (1450). Still, the dominating derivative was Grēkish 'of Greece or the Greeks, Grecian' attested throughout the whole Middle English period. Thēbān 'of or pertaining to Boeotian Thebes' (1395) did not have any -ish parallel. Two other similar adjectives are Tolletān 'for the city of Toledo, Spain' (1395) and Gällican 'Gallic, Gaulish' (1425). The latter adjective seems to have replaced the OE Gallisc 'Gaulish, belonging to Gaul, French'.

\subsection{5. $-\operatorname{in}(e)$}

Yet another suffix worth mentioning is -in(e). It appears in 17 adjectives and nouns derived from place-names as well as personal names and adds the sense 'of origin or belonging to'. However, none of the formations is coined on the

\footnotetext{
For Arabien and Sirīen see 5.1.1. above.
} 
same base as the attested $\mathrm{OE}$ and ME -ish derivatives. The -in(e) coinages discussed here include, e.g., Numantines (n. pl.) 'the people of Numantia, in northern Spain' (1387), Tartarin 'made of a costly fabric, perhaps a kind of silk, from (or originally from, or imported via) Tartary' (1400), Tarentine 'from or pertaining to Tarentum, Tarentine' (1440), Sclāvinn(e) 'an inhabitant of some Slavic territory' (1450), Alpine 'Alpine' (1475) and Molmutīne 'of Dunwallo Molmutius, British king and law-giver' (1475).

\section{2. of + Noun phrases}

As regards my second assumption, i.e., that the -ish adjectives were replaced by of + Noun phrases, I have decided to investigate what happened to the OE -ish formations coined on place-names attested in the Toronto Corpus but not found in the $M E D$. There are $86 \mathrm{OE}$ derivatives which were not inherited by Middle English.

In the case of almost half of these -ish words, i.e., 43, not only were the -ish derivatives not attested in the Middle English material available but also there were no base-words or any forms related to them. Thus, it seems there was no context for the usage of these words. Here belong, e.g., Cyrenisc, Geatisc, Lindisfarneisc, Sicilisc and Turonisc.

The other 14 -ish derivatives were replaced by adjectives or nouns with some competing suffixes (see above). ${ }^{10}$

Finally, $33 \mathrm{OE}$-ish adjectives were substituted for of + Noun phrases, where a Noun denotes 'a place-name' or sometimes 'an inhabitant(s) of a given place'. ${ }^{11}$ Here are some examples:

1) Arabī 'Arabia': the kyng of Arabe (1395), Fenyx of Arraby (1400), gumme of Araby (1425), the kyngdam off Arabe (1449);

2) Ethiope 'Ethiopia': pe folk of Ethiope (1350), Zara of Ethiop (1425), a man of Ethiopie (1425), kyng off Ethiope (1439), the kynge of Ethioppe (1475), folke of ethiopy (1500);

Ethiopien $^{12}$ 'an inhabitant of Ethiopia': men of Persis, Ethiopiens and Libiens with hem (1384), the puplis of Ethiopiens (1425), the queen of Ethiopiens (1425);

3) Frīse 'Frisia': Pe duk of ffryse (1400), Kyng Froderike of Fres (1440);

Frisōun 'an inhabitant of Frisia': Ricoldus duke of Frisons (1387), men of pis londe ffrisones (1398) (comp. OE ealra manna Frysiscra and Engliscra), a marchaunde of Fryslande (1400), a flote of Fresons (1450);

4) Milan 'Milan': of Melan grete Barnabo Viscounte (1375), they of Milayn were (1425), viij habergouns, some of meleyn and some of Westewale, of the which $v$ of

10 A few OE -isc derivatives were replaced with more than one parallel form (see above).

11 The numbers overlap since a few adjectives appeared both with competing suffixes and in of + Noun phrases.

12 See also 5.1.1. above. 
meleyn were delyvered to the College of Eyton (1456), a salat wyth a vesere of meleyn (1464), and $j$ herneyse complete of the touche of Milleyn (1465);

5) Pers(e) 'the land of the Persians, ancient Persia': Of kynges blood of Perce (1375), Egipt was vnder seuene kynges of Perse (1387), pe hool kyngdom of Pers (1387), De prowde prynce of Perce (1400), De kyng of Perse (1425), pe kyngdom of Persy (1425), pe diademe of Pers (1450), fyrst dyd wryte ... in the langage of Parce (1450), We have found in the reavme of Percy (1475), The Selentes..callid the holy stone..is founde in the lande of Perse (1500);

6) Sirie 'the Roman and Byzantine province of Syria, including Palestine': the langage of Sirie (1425), of Surre and of Ethyope the kyng (1470);

7) Tire 'the Levantine city of Tyre': of Tyro Appollonius (1390) (comp. OE ic eom Apollonius se tirisca ealdorman), the Prince of Tyr (1393).

A preliminary analysis of the OE derivatives inherited into Middle English and the newly derived ones exhibits similar tendencies.

\section{Conclusions}

The present paper endeavoured to establish the circumstances in which the $\mathrm{OE}$ suffix -isc with the sense 'of origin' underwent a significant decline in both the frequency and productivity in Middle English. The examination was preceded by the description of the semantics as well as frequency and productivity of the suffix in Old and Middle English. The analysis has been conducted on the basis of electronic corpora exhaustive of the preserved Old and Middle English linguistic material, i.e., the Toronto Corpus of Old English Texts for and the Middle English Dictionary online respectively. The investigation has revealed two factors which seem to have played influential role in the discussed development. One of these are some competing adjectival suffixes such as -ian, -ìte(s)/$\bar{\imath} t \overline{a n} e(s),-\bar{l} k,-\bar{a} n$ and $-i n(e)$, which were successful mostly due to having a semantic profile similar to that of -ish. The other attractive way of expressing the meaning 'of origin' of the OE -isc adjectives turned out to be the use of of + Noun constructions in Middle English. The latter development, however, seems somewhat contradictory in the light of the language economy tendency. At this point, a plausible explanation seems that of + Noun phrases were more communicative than parallel simple lexical items with an adjectival suffix since the phrases were able to clearly indicate their object(s) of reference, i.e., either 'a place-name' or 'an inhabitant(s) of a given place', whereas some discussed adjectives could have been ambiguous in this respect. 


\section{REFERENCES}

Bosworth, Joseph - T. Northcote Toller

1898-1921

[1964] An Anglo-Saxon dictionary. Glasgow - New York - Toronto: Oxford University Press.

Cameron, Angus - Ashley Crandell Amos - Antonette diPaolo Healey

2003 The Dictionary of Old English: A to F on CD-ROM. Toronto: University of Toronto.

Ciszek, Ewa

2002 "ME -lich(e)/-ly", Studia Anglica Posnaniensia 38:105-129.

2008a Word derivation in Early Middle English. Frankfurt/M: Peter Lang.

2008 b "On competition between OE -estre and OF -esse in Early Middle English", Kwartalnik Neofilolgiczny 55: 23-31.

in press "The semantic development and productivity of the OE suffix -isc in Middle English", Proceedings of The Sixth International Conference on Middle English (ICOME6), Cambridge, 24 - 26 July 2008.

Dalton-Puffer, Christiane

1996 The French influence on Middle English morphology: A corpus-based study of derivation. Berlin - New York: Mouton de Gruyter.

Dalton-Puffer, Christiane - Claire Cowie

2000 "Diachronic word-formation and studying changes in productivity over time: Theoretical and methodological considerations", in: Javier E. Diaz Vera (ed.), 410-437.

Diaz Vera, Javier E. (ed.)

2000 A changing world of words. Studies in English historical lexicography, lexicology and semantics. Amsterdam - New York: Rodopi.

Fisiak, Jacek

1965 Morphemic structure of Chaucer's English. University, Alabama: University of Alabama Press.

1968

[2004] A short grammar of Middle English. (6 $6^{\text {th }}$ edition.) Warszawa: Państwowe Wydawnictwo Naukowe.

Hogg, Richard (ed.)

1992 The Cambridge history of the English language. Vol. 1: The beginnings to 1066. Cambridge: Cambridge University Press.

Horobin, Simon

in press "Traditional English? Chaucerian methods of word-formation?", Neuphilologische Mitteilungen 110/2: 141-157.

Jespersen, Otto

1942 A modern English grammar on historical principles. Vol. 6: Morphology. London: Allen \& Unwin.

Kastovsky Dieter

1992 "Semantics and vocabulary", in: Richard Hogg (ed.), 290-408.

Kurath, Hans et al. (eds.)

1954- 2001 Middle English dictionary. Ann Arbor: University of Michigan Press.

Marchand, Hans

1969 Categories and types of Present-day English word formation: A synchronicdiachronic approach. München: C.H. Beck'sche Verlagsbuch-handlung. 
MED Online $=$ Middle English dictionary. $<$ http: $/ /$ ets.umdl.umich.edu $/ \mathrm{m} / \mathrm{med} />$ Murray, J.A.H. - Henry Bradley - W.A. Craigie - C.T. Onions.

1928

[1989] The Oxford English dictionary. ( $2^{\text {nd }}$ edition.) Oxford: Clarendon.

OED online $=$ The Oxford English dictionary. $<$ http://lib.amu.edu.pl/bazy/filologia.php $>$ Wright, Joseph - Elizabeth Mary Wright

1914 Old English grammar. London - Edinburgh: Oxford University Press. 